\title{
PEMBELAJARAN MENGENAL, MENULIS, DAN MENERBITKAN PUISI BERMUATAN NILAI UTAMA KARAKTER REVOLUSI INDUSTRI 4.0 DENGAN PENDEKATAN KONSTRUKTIVISME
}

\author{
Nurul Setyorini ${ }^{1}$ \\ Universitas Muhammadiyah Purworejo ${ }^{1}$ \\ bagya@umpwr.ac.id ${ }^{1}$ \\ Kadaryati $^{2}$ \\ Universitas Muhammadiyah Purworejo ${ }^{2}$ \\ yatikadar@umpwr.ac.id ${ }^{2}$ \\ Bagiya $^{3}$ \\ Universitas Muhammadiyah Purworejo ${ }^{3}$ \\ bagiya.purworejo@gmail.com ${ }^{3}$
}

\begin{abstract}
ABSTRAK
Ada tiga karakter utama era revolusi industri 4.0 antara lain: inovasi, otomasi dan transfer informasi. Tujuan dalam penelitian ini untuk mendeskripsikan dan menjelaskan Terdapat tiga hasil penelitian yang akan dibahas pada bagian ini, yaitu1 (1) penerapan nilai karakter utama era revolusi industri 4.0 dengan pendekatan konstruktivisme melalui pembelajaran mengenal puisi bagi mahasiswa di perguruan tinggi, (2) penerapan nilai karakter utama era revolusi industri 4.0 dengan pendekatan konstruktivisme melalui pembelajaran mencipta puisi bagi mahasiswa di perguruan tinggi, (3) penerapan nilai karakter utama era revolusi industri 4.0 dengan pendekatan konstruktivisme melalui pembelajaran menerbitkan puisi bagi mahasiswa di perguruan tinggi. Metode yang digunakan dalam penelitian ini adalah studi pustaka.Hasil penelitian ini menunjukkan bahwa penerapan proses pembelajaran nilai pendidikan karakter melalui pembelajaran puisi bagi mahasiswa perlu memperhatikan empat tahapan meliputi, (1) memilih materi, (2) memilih sumber belajar, (3) memilih objek puisi, (4) memilih model pembelajaran, dan (5) penerapan nilai karakter utama era revolusi industri 4.0 dengan pembelajaran. Kedua, dengan memperhatikan enam tahapan pembelajaran puisi maka dosen dan mahasiswa sudah mengintegrasikan nilai-nilai karakter 4.0 dalam pembelajaran puisi, baik inovasi, otomasi dan transfer informasi.
\end{abstract}

Kata kunci: nilai karakter, revolusi 4.0, puisi.

\section{A. PENDAhuluan}

Pembelajaran apresiasi puisi tidak lepas pada penanaman karakter positif. Puisi sebagai penggambaran keadaan masyarakat mempunyai potensi tinggi dalam perubahan karakter. Senada dengan pendapat Ernawati (2018); Suryaman (2017); dan Wiwita (2019) sastra 


\section{Lingua Rima: Jurnal Pendidikan Bahasa dan Sastra Indonesia \\ Vol. 11 No. 1 Januari 2022 \\ http://jurnal.umt.ac.id/index.php/lgrm}

memiliki potensi tinggi untuk membina, membentuk, membawa dan merangsang pembaca agar melakukan perubahan karakter.

Puisi merupakan karya sastra yang mengandung nilai etika dan karakter positif sebagai gambaran realita kehidupan masyarakat dan berbudaya. Puisi dapat dijadikan sebagai media maupun objek kajian pembelajaran guna mencapai pendidikan kejiwaan yang berorentasi pada pembentukan karakter. Melalui pembelajaran apresiasi puisi maka peserta didik akan mendapatkan nutrisi kepribadian positif. Puisi sebagai media maupun objek kajian dalam pembelajaran apresiasi puisi dapat berfungsi mendongkrak pemikiran dan media katarsis atau pembersih jiwa bagi peserta didik (Kanzunnudin, 2012; Yogyantoro, 2021).

Pembelajaran apresiasi puisi yang berorentasi pada pembentukan karakter maka akan mengimplementasikan nilai-nilai karakter positif dalam setiap tahap pembelajaranya. Karakter positif yang dapat diimplementasikan adalah nilai karakter utama pada revolusi industri 4.0. Penerapan karakter utama tersebut sejalan dengan fenomena pendidikan di era revolusi industri 4,0. Di era revolusi industri, dunia pendidikan dituntut mampu membekali para peserta didik dengan kualitas sumber daya manusia dan ketrampilan abad 21 (Risdianto, 2019; Syamsuar \& Reflianto, 2018).

Era revolusi industri 4.0 seperti saat ini telah memaksa seluruh aspek kehidupan untuk berperan maju. Pahlevi (2019) menyatakan salah satu konsekuensi dari revolusi industri 4.0 adalah lahirnya proses digitalisasi dalam segala bidang. Pendidikan termasuk sektor yang turut berperan dalam memaksimalkan kemajuan untuk menghadapi revolusi industri 4.0. Namun, kemajuan tersebuti dapat menimbulkan kemerosotan nilai-nilai kemanusiaan atau20 degridasi moral (Hanifa \& Dewi, 2021; Kurniawan, 2014). Oleh karena itu, pendidikan selain turut andil dalam memaksimalkan kemajuan di era revolusi industri maka pendidikan juga harus mampu mengatasi degridasi moral sebagai dampak negatifnya.

Pendidikan karakter bertujuan untuk membentuk pribadi insan yang berkeutamaan baik dari segi sosial, emosional, dan etis (Annisa, Wiliah, \& Rahmawati, 2020; Koesoema, 2010). Maunah (2015) dan Wati (2015) menambahkan pendidikan karakter bertujuan meningkatkan mutu penyelenggaraan dan hasil pendidikan di seluruh jenjang pendidikan yang berkaitan dengan pendidikan karakter peserta didik . Perguruan tinggi jurusan pendidikan merupakan penyelengara pendidikan berfokus menciptakan pendidik 


\section{Lingua Rima: Jurnal Pendidikan Bahasa dan Sastra Indonesia \\ Vol. 11 No. 1 Januari 2022 \\ http://jurnal.umt.ac.id/index.php/lgrm}

muda yang berkualitas, berahlakul karimah, dan mempunyai daya saing. Perguruan tinggi adalah satuan pendidikan penyelenggara pendidikan tinggi yang berkewajiban untuk ikut andil dalam pembentukan karakter bangsa (Hasanah, 2013).

Dengan demikian, perguruan tinggi mengaktualisasikan pendidikan karakter dalam setiap proses perkuliahan melalui mata kuliah yang disampaikan kepada mahasiswa. Mahasiswa pendidikan merupakan calon pendidik muda dan tutor yang kelak menjadi role model bagi peserta didinya. Sejalan dengan pendapat Khakiim (2017) dan Syahrobani (2021) guru merupakan role model menjadi pendukung pelaksanaan pendidikan karakter yang mudah diejawantahkan dalam kehidupan sehari-hari. Oleh karena itu, mahasiswa pendidikan haruslah memiliki sikap dengan kualitas yang baik.

Dalam mewujudkan tujuan pendidikan karakter di perguruan tinggi, maka dosen dapat mengaktualisasikan pembelajaran dengan nilai-nilai karakter yang sesuai dengan kebutuhan akademik, teknologi, dan jaman. Nilai-nilai karakter utama di era revolusi industri merupakan nilai-nilai karakter yang sesuai dengan kebutuhan akademik, teknologi, dan jaman seperti sekarang ini. Adanya revolusi industri 4.0 terdapat dampak terhadap pendidikan, yakni berkaitan dengan kompetensi yang perlu disiapkan agar mampu bertahan di era revolusi industri 4.0, maupun tantangan/dampak yang perlu diantisipasi (Kusnohadi, 2019). Perkembangan revolusi industri harus menjadi perhatian serius bagi semua pihakdalam rangka perkembangan karakter peserta didik sebagai generasi penerus bangsa. Oleh karena itu, kita harus memanfaatkan kesempatan untuk mengajar anak berpikir positif, menyaring informasi yang baik serta melatih pola pikir peserta didik (Dewo, 2018).

Ada tiga karakter utama era revolusi industri 4.0 antara lain: inovasi, otomasi dan transfer informasi (Kusnohadi, 2019; Usmar, 2021). Inovasi dalam pembelajaran dilakukan dengan mengembangkan keterampilan 6C, antara lain: Colaboration, Creativty, Critical Thinking, Citizenship, Character, dan Comunication (Tjahjani, Andahara, Evert, \& Maynanda, 2020).

Otomasi dalam konteks pembelajaran adalah kegiatan berpikir kritis dengan analisa yang mendalam. Menurut Rohmadi (2018), dosen dan mahasiswa di era Revolusi Industri 4.0 harus memiliki jiwa kreatif dan kritis dalam segala konteks kehidupan. Solusi kreatif 


\section{Lingua Rima: Jurnal Pendidikan Bahasa dan Sastra Indonesia \\ Vol. 11 No. 1 Januari 2022 \\ http://jurnal.umt.ac.id/index.php/lgrm}

menghadapi Revolusi Industri 4.0 yaitu dosen dan mahasiswa mampu memanfaatkan formula 4C, yaitu critical thingking, creativifity, communication, dan collaboration (Cahyono, 2019).

Transfer informasi merupakan penyebaran informasi melalui media digital dan internet. Transfer internet dalam pembelajaran dimaksudkan dengan memanfaatkan internet sebagai sumber dan media pembelajaran Pembelajaran sastra menggunakan di era digital diharapkan mampu meningkatkan motivasi belajar, menulis dan berkreativitas ( Wahyuni, 2021). Pembelajaran sastra digital mengacu teori belajar konstruktivisme. Teori belajar konstruktivisme adalah bahwa peserta didik membangun pengetahuan dan makna dari pengalaman mereka. Teori pembelajaran konstrutivisme adalah sebuah teori pendidikan yang menitikberatkan pada logika dan konseptual Fitri, 2020).

Salah satu mata kuliah di jurusan Pendidikan Bahasa dan Sastra Indonesia terdapat mata kuliah Apresiasi Puisi. Mata kuliah Apresiasi Puisi dapat mematrikan muatan nilainilai karakter utama revolusi industri 4.0 pada materi menulis dan menerbitkan puisi. Sejalan dengan penelitian Irma dan Bagiya (2021); dan Rustandi (2019) nilai pendidikan karakter dapat dipatrikan melalui materi apresiasi puisi. Penelitian ini memiliki persamaan dan perbedaan dengan penelitian (Irma \& Bagiya, 2021; Rustandi, 2019). Persamaan penelitian ini dengan penelitian Irma dan Bagiya (2021); dan Rustandi (2019) adalah samasama mengaktualisasi pendidikan karakter pada materi menulis puisi. Perbedaan penelitian ini dengan penelitian Irma dan Bagiya (2021); dan Rustandi (2019) adalah subjek penelitianya. Subjek penelitian ini adalah mahasiswa, sedangkan subjek penelitian Irma dan Bagiya (2021); dan Rustandi (2019) adalah siswa SD.

Penelitian ini mempunyai tujuan untuk mendeskripsikan dan menganalisis terkait (1) penerapan nilai karakter utama era revolusi industri 4.0 dengan pendekatan konstruktivisme melalui pembelajaran mengenal puisi bagi mahasiswa di perguruan tinggi, (2) penerapan nilai karakter utama era revolusi industri 4.0 dengan pendekatan konstruktivisme melalui pembelajaran mencipta puisi bagi mahasiswa di perguruan tinggi, (2) penerapan nilai karakter utama era revolusi industri 4.0 dengan pendekatan konstruktivisme melalui pembelajaran menerbitkan puisi bagi mahasiswa di perguruan tinggi.

\section{B. METODELOGI PENELITIAN}




\section{Lingua Rima: Jurnal Pendidikan Bahasa dan Sastra Indonesia \\ Vol. 11 No. 1 Januari 2022 \\ http://jurnal.umt.ac.id/index.php/lgrm}

Jenis penelitian yang digunakan adalah deskriptif kualitatif. Metode yang digunakan dalam penelitian ini adalah studi pustaka. Penelitian studi pustaka adalah rangkaian penelitian yang meliputi pengumpulan data, pembacaan, dan pencatatan, serta pengolahan data penelitian (Zed, 2018: 3). Data utama dalam penelitian ini meliputi buku dan artikel yang berkaitan dengan data-data yang dibutuhkan.

\section{HASIL DAN PEMBAHASAN}

Terdapat tiga hasil penelitian yang akan dibahas pada bagian ini, yaitu1 (1) penerapan nilai karakter utama era revolusi industri 4.0 dengan pendekatan konstruktivisme melalui pembelajaran mengenal puisi bagi mahasiswa di perguruan tinggi, (2) penerapan nilai karakter utama era revolusi industri 4.0 dengan pendekatan konstruktivisme melalui pembelajaran mencipta puisi bagi mahasiswa di perguruan tinggi, (3) penerapan nilai karakter utama era revolusi industri 4.0 dengan pendekatan konstruktivisme melalui pembelajaran menerbitkan puisi bagi mahasiswa di perguruan tinggi yang akan dijelaskan lebih lanjut di bawah ini:

\section{Penerapan Nilai Karakter Utama Era Revolusi Industri 4.0 Dengan Pendekatan Konstruktivisme Melalui Pembelajaran Mengenal Puisi Bagi Mahasiswa di Perguruan Tinggi}

Materi mengenal puisi di kalangan mahasiswa Pendidikan Bahasa dan Sastra Indonesia, terkait dengan : pengertian puisi, ciri-ciri puisi, ragam puisi lama, ragam puisi baru, dan ragam puisi kontemporer. Penerapan nilai karakter utama era revolusi industri 4.0 dengan pendekatan konstruktivisme melalui pembelajaran mengenal puisi bagi mahasiswa di perguruan tinggi dilakukan dengan beberapa tahap.

\section{a) Memilih Materi}

Berdasarkan beberapa materi yang tertuang pada paragraf di atas, dosen memilih materi yang cocok untuk menerapkan nilai pendidikan karakter utama era revolusi industri 4.0 dengan pendekatan konstruktivisme. Materi yang dianggap cocok untuk menerapkan nilai pendidikan karakter utama era revolusi industri 4.0 dengan pendekatan konstruktivisme salah satunya adalah ragam puisi baru. Materi ragam puisi baru yang akan disampaikan antara lain: puisi baru berdasarkan isi ( balada, himne, ode, epigram, romansa, elegi, dan satir.) 


\section{Lingua Rima: Jurnal Pendidikan Bahasa dan Sastra Indonesia \\ Vol. 11 No. 1 Januari 2022 \\ http://jurnal.umt.ac.id/index.php/lgrm}

dan puisi baru berdasarkan bentuk (distikon, terzina, kuatrain, kuint, oktaf/stanza, sektet, septima, dan soneta).

b) Memilih Sumber Belajar

Sumber belajar yang dipilih dalam mengajarkan materi ragam puisi baru sebaiknya buku elektronik dan artikel ilmiah. Referensi buku elektronik dan artikel ilmiah sebaiknya berdasarkan saran dosen dan hasil kerja mahasiswa. Pemanfaatan sumber belajar berupa buku elektronik dan artikel ilmiah diupayakan untuk memberikan pengalaman belajar mahasiswa dalam mencari informasi dan penerapan nilai karakter utama transfer informasi.

c) Memilih Objek Puisi

Puisi menjadi bagian terpenting dalam pembelajaran materi mengenal puisi baru. Objek puisi dalam materi mengenal puisi baru harus memuat nilai karakter utama era revolusi industri 4.0. Dengan demikian, dosen harus menyiapkan puisi-puisi yang mengandung nilai karakter utama revolusi industri 4.0, misalnya dosen memberikan contoh puisi dari ragam puisi baru yang bertema inovasi, teknologi, dan kreativitas.

d) Memilih Model Pembelajaran

Model pembelajaran yang sesuai dengan materi mengenai ragam puisi adalah model pembelajaran CTL (Contekstual Teaching and Learning). Model pembelajaran ini berasakan pada teori belajar konstruktivisme. Selain itu, model pembelajaran ini mengaktualisasikan nilai karakter utama era revolusi industri 4.0, seperti: colaboration, creativty, critical thinking, citizenship, character, dan comunication.

e) Penerapan Nilai Karakter Utama Era Revolusi Industri 4.0 dengan Pendekatan

Konstruktivisme Pembelajaran Memahami Ragam Puisi Baru

Penerapan Nilai Karakter Utama Era Revolusi Industri 4.0 dengan Pendekatan Konstruktivisme dilakukan dengan memanfaatkan model pembelajaran CTL. Langkahlangkah pembelajaran terdiri dari empat fase, antara lain invitasi, eksplorasi, penjelasasn dan solusi, dan pengambilan tindakan. Lebih jelasnya akan peneliti jelaskan pada paragraf berikut:

(1) Fase Invitasi 


\section{Lingua Rima: Jurnal Pendidikan Bahasa dan Sastra Indonesia \\ Vol. 11 No. 1 Januari 2022 \\ http://jurnal.umt.ac.id/index.php/lgrm}

Fase invitasi adalah fase pengenalan terhadap materi. Dalam fase ini mahasiiswa diharapkan untuk mengemukakan pengetahuan awal tentang konsep ragam puisi baru. Kegiatan mengemukakan yang dilakukan oleh mahasiswa tersebut merupakan penerapan nilai karakter komunikasi (communications). Setelah itu, dosen menyampaikan pertanyaan yang problematik tentang fenomena kehidupan sehari-hari atau pengalaman mahasiswa melalui kaitan konsep ragam puisi baru berdasarkan pendapat mahasiswa. Kegiatan ini dinamakan kegiatan berpikir kritis (critical thinking). Kegiatan berpikir kritis dilakukan dalam proses perkuliahan agar mahasiswa belajar berpikir secara rasional dan logis. Mahasiswa kembali diberikan kesempatan untuk mengomunikasikan dan mengaitkanya dengan konsep materi (comunication).

1) Eksplorasi

Fase eksplorasi adalah fase pengumpulan melalui penyelidikan lebih lanjut mengenai suatu informasi. Dosen merancang kegiatan pembelajaran yang menuntut mahasiswa untuk melakukan pengamatan, observasi, diskusi, dan hal lain sebagainya yang mampu meningkatkan rasa ingin tahu. Informasi yang diperoleh mahasiswa akan menjadi dasar dalam pemecahan masalah. Berkaitan dengan materi, dosen mengharapkan seluruh mahasiswa mencari, menelusuri, membaca berbagai literatur terkait ragam puisi baru, meliputi pengertian, ciri-ciri, dan contoh. Penelusuran dilakukan melalui buku, artikel, ebook, amupun media litaratur lainya. Pemanfaatan literatur lainya merupakan realisasi nilai karakter kreativitas (creativity). Kegiatan ini dianjurkan dilakukan secara kelompok sehingga informasi yang didapat lebih banyak. Anjuran secara kelompok merupakan penerapan nilai karakter kolaborasi dan berpikir kritis.

(2) Tahap Penjelasan dan Solusi

Tahap penjelasan merupakan tahap mahasiswa dapat memberikan penjelasanpenjelasan mengenai penemuannya.. Penjelasan ini kemudian dikuatkan oleh penjelasan dari dosen dan ditanggapi oleh mahasiswa lainnya sehingga ditemukanlah solusi bersama. Pada tahap ini, mahasiswa juga diharapkan untuk memberikan contoh puisi bertema kewarganegaraan. Dengan mencari contoh puisi bertema kewarganegaraan, maka dosen telah mengintegrasikan nilai karakter kewarganegaraan (citizenship). 


\section{Lingua Rima: Jurnal Pendidikan Bahasa dan Sastra Indonesia \\ Vol. 11 No. 1 Januari 2022 \\ http://jurnal.umt.ac.id/index.php/lgrm}

(3) Tahap Pengambilan Tindakan

Tahap pengambilan tindakan merupakan tahap akhir dalam pembelajaran kontekstual. Mahasiswa diharapkan mampu memberikan simpulan dari materi dan kegiatan yang telah dilakukan. Simpulan yang dilakukan berwujud tulisan dan lisan. Secara lisan mahasiswa mampu mengkomunikasikan di hadapan dosen dan mahasiswa lain. Komunikasi semacam ini merupakan realisasi nilai karakter komunikasi.

\section{Penerapan Nilai Karakter Utama Era Revolusi Industri 4.0 Dengan Pendekatan Konstruktivisme Melalui Pembelajaran Menulis Puisi Bagi Mahasiswa di Perguruan Tinggi}

Materi menulis puisi di kalangan mahasiswa Pendidikan Bahasa dan Sastra Indonesia, terkait dengan : menulis puisi lama, puisi baru, dan puisi kontemporer. Penerapan nilai karakter utama era revolusi industri 4.0 dengan pendekatan konstruktivisme melalui pembelajaran menulis puisi bagi mahasiswa di perguruan tinggi dilakukan dengan beberapa tahap.

\section{a) Memilih Materi}

Berdasarkan beberapa materi yang tertuang pada paragraf di atas, dosen memilih materi yang cocok untuk menerapkan nilai pendidikan karakter utama era revolusi industri 4.0 dengan pendekatan konstruktivisme. Materi yang dianggap cocok untuk menerapkan nilai pendidikan karakter utama era revolusi industri 4.0 dengan pendekatan konstruktivisme salah satunya adalah menulis puisi baru. Materi menulis puisi baru yang akan disampaikan antara lain:

1) tema dan judul

2) kata kunci.

3) diksi.

4) rima.

5) bait.

6) pengembangan puisi.

7) penutup puisi.

8) keterbacaan.

b) Memilih Sumber Belajar 


\section{Lingua Rima: Jurnal Pendidikan Bahasa dan Sastra Indonesia \\ Vol. 11 No. 1 Januari 2022 \\ http://jurnal.umt.ac.id/index.php/lgrm}

Sumber belajar yang dipilih dalam mengajarkan materi menulis puisi baru sebaiknya buku elektronik, antologi puisi, dan artikel ilmiah. Referensi buku elektronik, antologi puisi, dan artikel ilmiah sebaiknya berdasarkan saran dosen dan hasil kerja mahasiswa. Pemanfaatan sumber belajar berupa buku elektronik, antologi puisi, dan artikel ilmiah diupayakan untuk memberikan pengalaman belajar mahasiswa dalam mencari informasi dan penerapan nilai karakter utama transfer informasi.

\section{c) Memilih Objek Puisi}

Puisi menjadi bagian terpenting dalam pembelajaran materi menulis puisi baru. Objek puisi dalam materi mengenal puisi baru harus memuat nilai karakter utama era revolusi industri 4.0. Dengan demikian, dosen harus mencontohkan puisi-puisi yang mengandung nilai karakter utama revolusi industri 4.0, misalnya dosen memberikan contoh puisi baru yang bertema inovasi, teknologi, dan kreativitas.

d) Memilih Model Pembelajaran

Model pembelajaran yang sesuai dengan materi mengenai puisi baru adalah model pembelajaran konstruktivisme. Konstruktitivisme adalah suatu landasan berpikir kritis berdasarkan pengalaman yang nyata (Susilana,2005 : 45). Penerapan model pembelajaran ini dalam menulis puisi agar nilai pendidikan karakter utama revolusi industri 4.0 teraktualisasi. Adapun nilai utama yang teraktualisasi pada pembelajaran menulis puisi dengan model pembelajaran kontekstual adalah otomasi. Dalam dunia pendidikan, otomasi yang diterapkan adalah dengan memanfaatkan formula 4C, yaitu critical thingking, creativifity, communication, dan collaboration (Cahyono, 2019).

e) Penerapan Nilai Karakter Utama Era Revolusi Industri 4.0 dengan Pendekatan Konstruktivisme Pembelajaran Menulis Puisi Baru

Penerapan Nilai Karakter Utama Era Revolusi Industri 4.0 dengan Pendekatan Konstruktivisme dilakukan dengan beberapa tahap, antara lain:

(1) Orientasi

Mahasiswa diberi kesempatan untuk mengembangkan motivasi dalam mempelajari menulis puisi baru. Motivasi dapat dilakukan dengan memamerkan karya dosen terkait penulisan puisi yang sudah dipublikasikan baik di koran maupun antologi 


\section{Lingua Rima: Jurnal Pendidikan Bahasa dan Sastra Indonesia \\ Vol. 11 No. 1 Januari 2022 \\ http://jurnal.umt.ac.id/index.php/lgrm}

puisi. Motivasi selanjutnya, dosen memberikan arahan agar mahasiswa juga diharapkan untuk menulis puisi di koran dan antologi puisi yang diterbitkan di penerbit minor. Dengan motivasi seperti ini, dosen telah menerapkan nilai karakter utama transfer teknologi.

Kemudian, mahasiswa diberi kesempatan untuk mengadakan observasi terhadap topik menulis puisi baru yang hendak dipelajari. Topik yang harus ditulis mahasiswa, seputar teknologi, otomasi, dan informasi. Dalam tahap ini, mahasiswa harus mengobservasi topik seputar teknologi, otomasi, dan informasi agar kegiatan menulis yang dilakukan sesuai dengan topik. Kegiatan ini merupakan implementasi nilai karakter utama era revolusi industri 4,0 karena menerapkan salah satu formula 4C, yakni critical thinking (berpikir kritis).

\section{(2) Elicitasi}

Mahasiswa dibantu untuk mengungkapkan idenya secara jelas dengan berdiskusi, menulis, membuat poster, dan lain-lain. Mahasiswa diberi kesempatan untuk mendiskusikan apa yang diobservasikan, dalam wujud tulisan, gambar, ataupun poster. Kegiatan ini merupakan implementasi nilai karakter utama era revolusi industri 4,0 karena menerapkan formula 4C, colaboration, comunication, dan creativity. Colaboration diwujudkan dalam bentuk diskusi ide dan observasinya. Communication diwujudkan dalam bentuk presentasi ide dan hasil observasinya. Creativity diwujudkan dalam kegiatan menulis ide dalam poster. Dalam kegiatan ini, mahasiswa terlebih dahulu membuat idei di sebuah poster untuk dinilai dosen dan mahasiswa lainya.

(3) Restrukturisasi ide

Dalam hal ini ada tiga, yaitu :

(a) Klarifikasi ide adalah kegiatan.meminta masukan terkait ide yang telah dibuat dalam poster untuk mendapatkan masukan ide lainya. Jika ide yang diberikan teman cocok bisa menjadi masukan yang perlu diadaptasi oleh penulis.

(b) Membangun ide yang baru 


\section{Lingua Rima: Jurnal Pendidikan Bahasa dan Sastra Indonesia \\ Vol. 11 No. 1 Januari 2022 \\ http://jurnal.umt.ac.id/index.php/lgrm}

Ide baru dapat terjadi jika masukan yang diterima menulis cocok dan dianggap membangun ide yang dimiliiikinya.

(c) Mempelajari ide barunya dengan eksperimen.

Ide baru yang sudah dibuat kemudian diuji dengan suatu percobaan atau persoalan yang baru.

Kegiatan rekonstruksi ide merupakan tahap aktualisasi nilai karakter utama era revolusi industri 4.0 berupa otomasi karena menerapkan 2 formula c, yakni colaboration dan comunication.

(4) Penggunaan ide dalam banyak situasi.

Ide atau pengetahuan yang telah dibentuk oleh mahasiswa perlu diaplikasi pada beragam persoalan topik yang dihadapi. Hal ini akan menambah pengetahuan mahasiswa.

(5) Review.

Kegiatan mereview dilakukan dengan menghubungkan ide dengan aplikasi dengan kehidupan nyata. Penghubungan ide dengan kehidupan nyata merupakan prinsip dari model pembelajaran yang digunakan.Kegiatan mereview juga menjadi tahap memperbaiki ide.

Setelah direview, dosen mengharapkan puisi dari mahasiswa untuk dipublikasikan. Publikasi dapat dilakukan dengan menerbitkan di koran ataukan di penerbit minor. Dengan tugas akhir, seperti ini maka dosen sudah menerapkan nilai karakter utama transfer teknologi.

\section{Penerapan Nilai Karakter Utama Era Revolusi Industri 4.0 Dengan Pendekatan Konstruktivisme Melalui Pembelajaran Menerbitkan Puisi Bagi Mahasiswa di Perguruan Tinggi}

Materi menulis puisi di kalangan mahasiswa Pendidikan Bahasa dan Sastra Indonesia, terkait dengan : menulis puisi lama, puisi baru, dan puisi kontemporer. Penerapan nilai karakter utama era revolusi industri 4.0 dengan pendekatan konstruktivisme melalui pembelajaran menerbitkan puisi bagi mahasiswa di perguruan tinggi dilakukan dengan beberapa tahap. 


\section{Lingua Rima: Jurnal Pendidikan Bahasa dan Sastra Indonesia \\ Vol. 11 No. 1 Januari 2022 \\ http://jurnal.umt.ac.id/index.php/lgrm}

\section{a) Memilih Materi}

Berdasarkan beberapa materi yang tertuang pada paragraf di atas, dosen memilih materi yang cocok untuk menerapkan nilai pendidikan karakter utama era revolusi industri 4.0 dengan pendekatan konstruktivisme. Materi yang dianggap cocok untuk menerapkan nilai pendidikan karakter utama era revolusi industri 4.0 dengan pendekatan konstruktivisme salah satunya adalah menerbitkan puisi baru. Materi menerbitkan puisi baru yang akan disampaikan antara lain:

1) Pengertian penerbit

2) ragam penerbit

3) langkah-langkah menerbitkan di penerbit mayor

4) langkah-langkah menerbitkan di penerbit minor.

b) Memilih Sumber Belajar

Sumber belajar yang dipilih dalam mengajarkan materi menerbitkan puisi baru sebaiknya buku elektronik, antologi puisi, dan artikel ilmiah. Referensi buku elektronik, antologi puisi, dan artikel ilmiah sebaiknya berdasarkan saran dosen dan hasil kerja mahasiswa. Pemanfaatan sumber belajar berupa buku elektronik, antologi puisi, dan artikel ilmiah diupayakan untuk memberikan pengalaman belajar mahasiswa dalam mencari informasi dan penerapan nilai karakter utama transfer informasi.

\section{c) Memilih Objek Puisi}

Puisi menjadi bagian terpenting dalam pembelajaran materi menulis puisi baru. Objek puisi dalam materi mengenal menerbitkan puisi baru harus memuat nilai karakter utama era revolusi industri 4.0. Dengan demikian, dosen harus mencontohkan puisi-puisi yang sudah diterbitkan dan mengandung nilai karakter utama revolusi industri 4.0, misalnya dosen memberikan contoh antologi puisi baru yang bertema inovasi, teknologi, dan kreativitas.

d) Memilih Model Pembelajaran

Model pembelajaran yang sesuai dengan materi mengenai puisi baru adalah model pembelajaran konstruktivisme. Konstruktitivisme adalah suatu landasan berpikir kritis berdasarkan pengalaman yang nyata (Susilana,2005 : 45). Penerapan model pembelajaran ini dalam menulis puisi agar nilai pendidikan karakter utama revolusi industri 4.0 


\section{Lingua Rima: Jurnal Pendidikan Bahasa dan Sastra Indonesia \\ Vol. 11 No. 1 Januari 2022 \\ http://jurnal.umt.ac.id/index.php/lgrm}

teraktualisasi. Adapun nilai utama yang teraktualisasi pada menerbitkan puisi baru dengan model pembelajaran kontekstual adalah otomasi. Dalam dunia pendidikan, otomasi yang diterapkan adalah dengan memanfaatkan formula 4C, yaitu critical thingking, creativifity, communication, dan collaboration (Cahyono, 2019).

e) Penerapan Nilai Karakter Utama Era Revolusi Industri 4.0 dengan Pendekatan Konstruktivisme Pembelajaran Menulis Puisi Baru

Penerapan Nilai Karakter Utama Era Revolusi Industri 4.0 dengan Pendekatan Konstruktivisme tipe snowbal. Penerapan pembelajaran dengan pendekatan konstruktivisme tipe snowball dilakukan dengan beberapa tahap, antara lain:

1) Tahap Prapenulisan

Tahap prapenulisan yang dimaksud bukan prapenulisan puisi, melainkan prapenulisan antologi. Dalam hal ini, mahasiswa sebaiknya sudah menentukan penerbit minor apa yang akan dituju dan bagaimana templatenya. Penerbit minor yang beredar di media sosial sudah banyak sehingga mahasiswa dapat memilih salah satu penerbit. Penentuan atau pencarian penerbit merupakan salah satu kegiatan critical thinking bagi mahasiswa.

\section{2) Tahap Penulisan}

Tahap penulisan yang dimaksud adalah tahap penulisan antologi. Pada pembelajaran sebelumnya, mahasiswa sudah menyusun sebuah puisi. Oleh karena itu, tahap ini adalah penerbitan puisi yang sudah disusun menjadi antologi bersama. Penyusunan antologi disesuaikan dengan template buku. Berikut contoh template buku dari salah satu penerbit. 


\section{Lingua Rima: Jurnal Pendidikan Bahasa dan Sastra Indonesia \\ Vol. 11 No. 1 Januari 2022 \\ http://jurnal.umt.ac.id/index.php/lgrm}

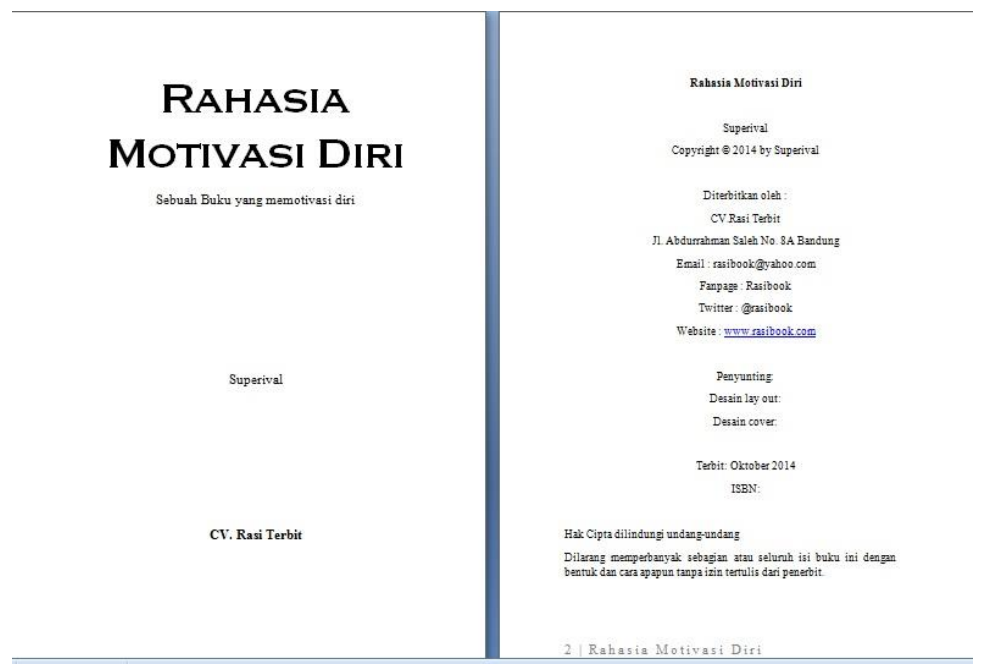

Kegiatan menyusun antologi puisi merupakan realisasi dari nilai karakter di era revolusi industri 4.0, seperti: kreativitas, kerja sama, dan transfer teknologi. Kreativitas yang dimaksud adalah penyusunan puisi menjadi antologi. Kerja sama yang dimaksud adalah kerja sama antar mahasiswa dalam menyusun antologi puisi. Transfer teknologi yang dimaksud adalah komersalisasi nilai sastra menjadi suatu barang yang inovatif dan dapat dinikmati oleh banyak orang karena mempunyai nilai/ keilmuan yang sesuai dengan bidang masing-masing.

\section{3) Tahap Revisi}

Tahap revisi adalah tahap perbaikan antologi puisi dengan kaca mata pembaca. Oleh karena, antologi merupakan karya pembaca dan belum diterbitkan maka dosen berlaku sebagai penilai/ reviewer terhadap antologi puisi. Setelah antologi dinilai dan diperbaiki maka para mahasiswa memperbaiki dan selanjutnya dapat diteruskan ke penerbit untuk diterbitkan. Tahap ini maka pembelajaran sudah mengimplementasikan nilai karakter era revolusi industri 4.0, antara lain: kerja sama dan transfer teknologi. Kerja sama disini adalah kerja sama yang dilakukan seluruh mahasiswa dengan dosen untuk menciptakan karya antologi yang baik dan bernilai, sedangkan transfer teknologi dilakukan dengan menerbitkan buku antologi puisi dengan memanfaatkan teknologi dan setelah terbit dapat dipamerkan melalui media teknologi seperti media sosial instagram, face book, youtube, maupun tiktok.

\section{SIMPULAN DAN SARAN}

Berdasarkan hasil dan pembahasan diperoleh tiga simpulan. Pertama, penerapan proses pembelajaran nilai pendidikan karakter melalui pembelajaran puisi bagi mahasiswa 


\section{Lingua Rima: Jurnal Pendidikan Bahasa dan Sastra Indonesia \\ Vol. 11 No. 1 Januari 2022 \\ http://jurnal.umt.ac.id/index.php/lgrm}

perlu memperhatikan empat tahapan meliputi, (1) memilih materi, (2) memilih sumber belajar, (3) memilih objek puisi, (4) memilih model pembelajaran, dan (5) penerapan nilai karakter utama era revolusi industri 4.0 dengan pembelajaran. Kedua, dengan memperhatikan enam tahapan pembelajaran puisi maka dosen dan mahasiswa sudah mengintegrasikan nilai-nilai karakter 4.0 dalam pembelajaran puisi, baik inovasi, otomasi dan transfer informasi.

\section{E. DAFTAR PUSTAKA}

Annisa, M. N., Wiliah, A., \& Rahmawati, N. (2020). Pentingnya Pendidikan Karakter pada Anak Sekolah Dasar di Zaman Serba Digital. Bintang : Jurnal Pendidikan Dan Sains, 2(1), 35-48.

Fitri, Yunela. (2020). Implementasi Penerapan Teori Konstruktivisme dalam Proses Pembelajaran di Sekolah Dasar. Workshop Pembelajaran di Sekolah Dasar, 3(4), 1300-1307.

Cahyono, B. E. H. (2019). Pembelajaran Sastra Berbasis Pengembangan Kreativitas di Era Revolusi Industri 4.0. Prosiding Seminar Nasional "Inovasi Pembelajaran Bahasa Indonesia Di Era Revolusi Industri 4.0."

Dewo, S. A. (2018). Era Revolusi Industri 4.0 harus Diikuti Penguatan Pendidikan Karakter. Retrieved from siar.com website: https://siar.com/era-revolusi-industri-4-0harus-diikuti-penguatan-pendidikan-karakter/

Ernawati, Y. (2018). Membangun Karakter melalui Pembelajaran Sastra: Problematika Pembinaan Karakter. Jurnal Ilmiah Bina Edukasi Universitas Bina Darma, 11(1).

Hanifa, S., \& Dewi, D. A. (2021). Kesadaran Patriotik Di Kalangan Mahasiswa. Jurnal Pendidikan Indonesia, 2(4), 757-763.

Hasanah. (2013). Implementasi Nilai-Nilai Karakter Inti di Perguruan Tinggi. Jurnal Pendidikan Karakter, 4(2), 186-195.

Henriksen, D., Richardson, C., \& Mehta, R. (2017). Design thinking: A creative approach to educational problems of practice. Thinking Skills and Creativity, 26, 140-153. https://doi.org/doi.org/10.1016/j.tsc.2017.10.001

Irma, C. N., \& Bagiya. (2021). Aktualisasi Nilai Pendidikan Moral Melalui Pembelajaran Menulis Puisi bagi Siswa di Sekolah Dasar. Jurnal Bahtera - Jurnal Pendidikan Bahasa Sastra Dan Budaya, 8(2). 


\section{Lingua Rima: Jurnal Pendidikan Bahasa dan Sastra Indonesia}

Vol. 11 No. 1 Januari 2022

http://jurnal.umt.ac.id/index.php/lgrm

Kanzunnudin, M. (2012). Peran Sastra Dalam Pendidikan Karakter. Prosiding Seminar Nasional Pendidikan: Pendidikan Untuk Kejayaan Bangsa, 195-204. Yogyakarta: Universitas Sanata Dharma.

Khakiim, U. (2017). Guru sebagai Role Model Individu Berkarakter bagi Peserta Didik untuk Mendukung Keberhasilan Pelaksanaan Pendidikan Karakter. Karya Ilmiah Dosen, 3(2), 217-230.

Koesoema, D. (2010). Pendidikan Karakter: Strategi Mendidik Anak di Zaman Global (A. A. Nusantara, Ed.). Jakarta: Grasindo.

Kurniawan, S. (2014). Pendidikan Karakter: Konsepsi dan Implementasinya Secara Terpadu di Lingkungan Keluarga, Sekolah, Perguruan Tinggi, Masyarakat. Yogyakarta: Ar-ruzz Media.

Kusnohadi. (2019). Tiga Karakter Utama Revolusi Industri 4.0. Retrieved from lpmpjatim.kemdikbud.go.id website: https://lpmpjatim.kemdikbud.go.id/site/detailpost/tiga-karakter-utama-revolusiindustri-4-0

Maunah, B. (2015). Implementasi Pendidikan Karakter dalam Pembentukan Kepribadian Holistik Siswa. Jurnal Pendidikan Karakter, (1).

Pahlevi, I. (2019). Revolusi Industri 4.0 dan Pembangunan Ekonomi Berkelanjutan. In C. M. Firdausy, A. Suryana, R. Nugroho, \& Y. B. Suhartoko (Eds.), Prosiding Seminar Nasional Bagian II Pusat Penelitian Badan Keahlian DPR RI. Jakarta: Pusat Penelitian Badan Keahlian DPR RI.

Risdianto, E. (2019). Analisis Pendidikan Indonesia di Era Revolusi Industri 4.0. Bengkulu.

Rohmadi, M. (2018). Strategi dan Inovasi dalam Pembelajaran Bahasa dan Sastra Indonesia di Era Industri 4.0. Pertemuan Ilmiah Bahasa Dan Sastra Indonesia (PIBSI) XL 2018.

Rustandi, A. (2019). Pembelajaran Menulis Puisi Anak Berorientasi Karakter dengan Menggunakan Model Multisensori pada Siswa Kelas VI Sekolah Dasar (SD) Negeri Rahayu 01 Kabupaten Bandung. LITERASI: Jurnal Ilmiah Pendidikan Bahasa, Sastra Indonesia Dan Daerah, 9(1).

Suryaman, M. (2017). Sastra, Media Massa, dan Literasi Membaca Siswa Indonesia. Prosiding Seminar Internasional PIBSI XXXIX. Semarang.

Syahrobani, I. (2021). Urgensi Role Model Guru dalam Pembentukan Siswa Berkarakter dengan 5M (pp. 1-6). pp. 1-6. Kuningan: Universitas Islam Al-Ihya Kuningan. 


\section{Lingua Rima: Jurnal Pendidikan Bahasa dan Sastra Indonesia \\ Vol. 11 No. 1 Januari 2022 \\ http://jurnal.umt.ac.id/index.php/lgrm}

Syamsuar, \& Reflianto. (2018). Pendidikan dan Tantangan Pembelajaran Berbasis

Teknologi Informasi di Era Revolusi Industri 4.0. E-Tech : Jurnal Ilmiah Teknologi

Pendidikan, 6(2).

Tjahjani, L., Andahara, C., Evert, C., \& Maynanda, I. (2020). Inovasi Menghadapi Revolusi Industri 4.0 dan Masyarakat 5.0. Ponorogo: Uwais Inspirasi Indonesia.

Usmar. (2021). PA GMNI Di Tengah Perubahan Arus Generasi. Retrieved from infokongres.com website: https://infokongres.com/pa-gmni-di-tengah-perubahan-arusgenerasi/

Wahyuni, Dewi. 2021. Meningkatkan Pembelajaran Sastra Melalui Perkembangan Era Digital. Jurnal Edukasi Kultura, 7(1), 1-10.

Wati, F. Y. L. (2015). Pengembangan Pendidikan Karakter di Sekolah Dasar/Madrasah Ibtidaiyah. Jurnal Mitra PGMI, 1(1), 97-112.

Wiwita, L. (2019). Pembelajaran Sastra dan Implikasinya terhadap Pendidikan Karakter Siswa. Jurnal Edukasi Kultura: Jurnal Bahasa, Sastra Dan Budaya, 6(1).

Yogyantoro. (2021). Apresiasi Sastra Lahirkan Profil Pelajar Pancasila. Retrieved from Poskita website: https://poskita.co/2021/10/06/apresiasi-sastra-lahirkan-profil-pelajarpancasila/ 